\title{
SIRI MARRIAGE PRACTICES IN MAKMUR VILLAGE COMMUNITY, IN GAMBUT, BANJAR DISTRICT
}

\author{
Rahmiyati \\ Fakultas Syariah Universitas Islam Negeri Antasari \\ Jalan Ahmad Yani Km. 4.5 Banjarmasin, Kalimantan Selatan \\ Email: rahmivati0202@gmail.com \\ Nadiyah \\ Fakultas Syariah Universitas Islam Negeri Antasari \\ Jalan Ahmad Yani Km. 4.5 Banjarmasin, Kalimantan Selatan \\ Email: Nadiyah@uin-antasari.ac.id \\ Diana Rahmi \\ Fakultas Syariah Universitas Islam Negeri Antasari \\ Jalan Ahmad Yani Km. 4.5 Banjarmasin, Kalimantan Selatan \\ Email: dianarahmi54@gmail.com
}

\begin{abstract}
Abstrak: Penelitian ini dilatarbelakangi oleh adanya praktik walimah pernikahan siri pada masyarakat Desa Makmur Kecamatan Gambut Kabupaten Banjar. Prosesi akad nikah pada pernikahan siri yang dilakukan oleh masyarakat Desa Makmur dilaksanakan tanpa dihadiri oleh Pegawai Pencatat Nikah dan tanpa sepengetahuan pihak KUA. Meskipun begitu, ternyata setelah akad nikah berlangsung diadakanlah walimah pada pernikahan siri tersebut. Penelitian ini merupakan penelitian hukum empiris yang bersifat studi kasus, dengan menggunakan pendekatan kualitatif. Penulis menggali data yang diperlukan dengan melakukan wawancara mendalam terhadap subjek yang diteliti. Hasil temuan dari penelitian ini adalah walimah pernikahan siri yang dipraktikkan oleh masyarakat Desa Makmur diselenggarakan seperti walimah pernikahan yang resmi. Walimah tersebut diselenggarakan secara terang-terangan dengan mengundang keluarga dan masyarakat sekitar. Mengadakan walimah pernikahan siri merupakan suatu perbuatan yang sudah biasa dilakukan (kebiasaan), oleh karena itu apabila walimah pernikahan siri terus menerus dilakukan maka akan berakibat bertambah banyak terjadi pernikahan siri pada masyarakat, khususnya di Desa Makmur.
\end{abstract}

Kata Kunci: Walimah, Pernikahan, Siri,

\begin{abstract}
This research is motivated by the existence of the practice of marriage series in the Makmur Village community, Gambut Banjar District, South Borneo. The procession of a marriage contract at a series of marriages conducted by the people of Makmur Village was carried out without the attendance of the Registrar of Marriage and the knowledge of the Religious Affairs Office (KUA). Even so, it turned out that after the marriage contract took place it was held at Siri marriage. This research is empirical legal research which is a case study, using a qualitative approach. The author delves into the data needed by conducting in-depth interviews with the subject under study. The findings of this study are that the marriage of Siri which is practiced by the people of Desa Makmur is held like the official marriage ceremony. Walimah was held
\end{abstract}


openly by inviting family and surrounding communities. Holding a Siri marriage is an act that is usually done, therefore if Siri marriage is done continuously it will result in more siri marriages occurring in the community, especially in Makmur Village.

Keywords: Walimah, Siri, Marriage, practice.

\section{INTRODUCTION}

Marriage is a contract between a prospective bridal wife and a bridal wife based on both parties' will to be agreed by the other party (guardian) in the terms and conditions of the by Islamic law, to justify a mixture of the two so that each other wants to be allies in household life. ${ }^{1}$

Islam has arranged well regarding marriage, one of which is the rules regarding harmony and conditions for marriage, which is a valid marriage if the pillars and conditions are met. ${ }^{2}$ In addition to Islamic law, it turns out that law in Indonesia also regulates marriages contained in Law Number 1 of 1974 concerning Marriage and Government Regulation Number 9 of 1975 concerning Implementation of Law Number 1 of 1974 concerning Marriage and also regulated in Presidential Instruction Number 1 of 1991 concerning the Compilation of Islamic Law.

${ }^{1}$ Beni Ahmad Saebani, Fiqh Munakahat (Buku I) (Bandung: Pustaka Setia, 2001), p. 14.

2 Anwar Hafidzi and Norwahdah Rezky Amalia, "Marriage Problems Because of Disgrace (Study of Book Fiqh Islam Wa Adilâtuh and Kitâb alNikâh)," AL-IHKAM: Jurnal Hukum \& Pranata Sosial 13, no. 2 (2018): 273-290; Arshad Munir and
One of the rules regarding marriage contained in the Act is regarding the registration of marriage. Marriage registration is very important to do because it has juridical implications in various aspects as a result of the marriage. ${ }^{3}$

Article 5 Compilation of Islamic Law (KHI) in Indonesia, which reads:

(1) To guarantee order for the Islamic community every marriage must be recorded.

(2) The registration of the marriage as referred to in paragraph (1), shall be carried out by the Registrar of Marriage as regulated in Law Number 22 of 1946 in conjunction with Law Number 32 of 1954.

The registration of marriage as prescribed by Article $5 \mathrm{KHI}$ is under that regulated in Article 2 Paragraph (2) of Law Number 1 of 1974 concerning Marriage, namely: "Every marriage is recorded according to the applicable laws and

Naseem Akhter, "Marriage in Islam: An Analytical Study with a Special Focus on Non-Traditional Marriages in Pakistan.," FWU Journal of Social Sciences 12, no. 2 (2018).

${ }^{3}$ Abd. Kadir Syukur, Hukum Perkawinan di Indonesia (Barito Kuala: LPKU, 2015), hlm. 50. 
regulations." A marriage that is carried out without a registration procedure is known as a siri marriage. Siri marriage according to KHI does not have legal force. Syrian marriages are legal according to religion, but their rights are not guaranteed by statutory regulations. So, during the marriage of Siri a child is born so the child has no legal power (not recognized if a civil problem arises) and is considered illegal by law, so only has a civil relationship with his mother. ${ }^{4}$

Marriage registration aims to realize marital order in the community. ${ }^{5}$ This is an effort regulated in legislation to protect the dignity and sanctity of miśäqan galizan marriage. ${ }^{6}$ It is difficult to expect the legal awareness of some Indonesian people to have the awareness to carry out the registration of marriages that have been carried out. As found by the writer in the village of Makmur, Gambut District, Banjar Regency.

Siri marriage is an act that is common to the people of Makmur Village. The author feels interested to research related to the marriage of Siri because in practice also held Walimah. Holding walimah is an

4 Abd. Shomat, Hukum Islam: Penormaan Prinsip Syariah Dalam Hukum Indonesia (Jakarta: Kencana, 2010), p. 298.

${ }^{5}$ Kirsten Lind Seal, William J. Doherty, and Steven M. Harris, "Confiding about Problems in Marriage and Long-Term Committed Relationships: A act that is highly recommended. As the Prophet said. following:

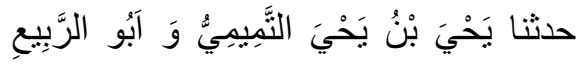

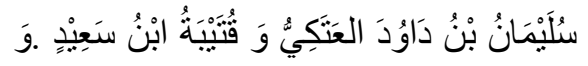

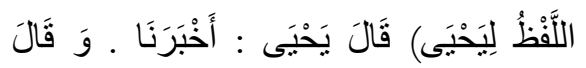

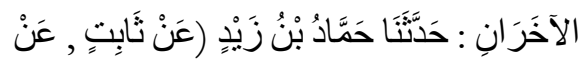

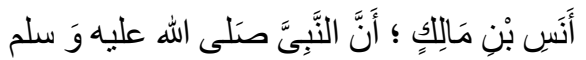

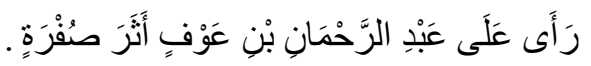

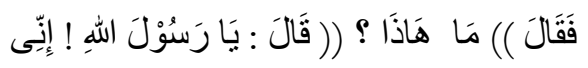

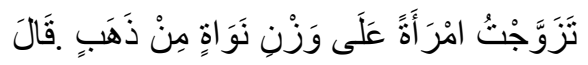

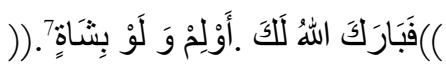

"Yahya bin Yahya At-Tamimi, Abu ar-Rabi 'Sulaiman bin Dawud AlAtaki, and Qutaibah bin Sa'id told us - with the editorial from Yahya(Yahya said lafazh: Preaching to us while the other two narrators say: Hammad bin Zaid told us) from Thabit, from Anas bin Malik; that the Holy Prophet. see Abdurrahman bin Awf, while there is a yellow stain used in fragrance (perfume) on one part of the body or Abdurrahman bin Awf's clothes. Then the Prophet asked, "What is this?" Abdurrahman answered, "O Messenger of Allah, I just married a

National Study," Journal of marital and family therapy 42, no. 3 (2016): 438-450.

${ }^{6}$ Ahmad Rofiq, Hukum Islam di Indonesia (Jakarta: Raja Grafindo Persada, 1995), p. 107.

${ }^{7} \mathrm{Abī}$ al-Husaini Muslim bin al-Hajjāj al-Qusyairi an-Naisābūri, Saḩịh Muslim, juz II (Indonesia: Maktabatu Rihlan, t.t.), p. 1042. 
woman with the gold of one or nuwaat (five dirhams)." The Holy Prophet. said, "May Allah bless you. Hold a walimah even by cutting a goat. "8

Holding walimah at a Siri marriage means that the Siri marriage is intentionally announced to the public at large. ${ }^{9}$ Typically, as I know, siri marriages are not only recorded but are not openly held or are not held by Walimah, for example, one of the causes of siri marriages is that a man who wants to remarry a second wife but does not get permission from the first wife so that the marriage This is done in a series and not disseminated to the public or is not held even so it is not known by his first wife.

Based on observations related to Walimah at Siri marriage, the writer knows that the procession of the marriage contract at Siri marriage conducted by the people of Makmur Village was carried out without being attended by the Registrar of Marriage and without the knowledge of the KUA. Even so, it turned out that after the marriage contract took place it was held at Siri marriage. Walimah at Siri

\footnotetext{
${ }^{8}$ An-Nawawi, Syarah Shabih Muslim, Volume IX, trans. Ahmad Khotib (Jakarta: Pustaka Azzam, 2011), p. 600.

${ }^{9}$ Nasaiy Aziz, "The Great Phenomenon of Online Sirri Marriage for Male and Female," Budapest International Research and Critics Institute (BIRCIJournal): Humanities and Social Sciences 1, no. 3 (2018): 445-450; Mukhtaruddin Bahrum, "Legalisasi Nikah Sirri Melalui Isbat Nikah Menurut
}

marriage is held as one of the actions to announce to the public that marriage has taken place. $^{10}$

Walimah Siri marriage conducted by the people of the Village Makmur carried out like Walimah in general. Therefore, issues arise regarding the actions of the people who hold Walimah in Siri marriages if done continuously, it is feared that there will be an alignment of marriage registration with Siri marriages so that with the existence of these marriages, marriage registration will be aborted, and in the end, the purpose of the registration is not reached. The people of Desa Makmur openly hold a Siri marriage and openly hold a Siri marriage event. Even though Siri marriage is held even in the context of announcing, the marriage is still not recognized by the state and will have legal consequences.

Based on the background of the problems mentioned above, the problem formulation in this research is as follows, What is the description of the practice of siri marriage in the people of Makmur Village? What is the reason for the

Kompilasi Hukum Islam," Jurnal Diskursus Islam 1, no. 2 (2013): 210-230; Rihlatul Khoiriyah, "Aspek Hukum Perlindungan Perempuan Dan Anak Dalam Nikah Siri," Sawwa: Jurnal Studi Gender 12, no. 3 (2018): 397-408.

10 Zainuddin \& Afwan Zainuddin, Kepastian Hukum Perkawinan Siri dan Permasalahannya Ditinjau dari Undang-Undang Nomor 1 Tabun 1974 (Deepublish, 2017). 
occurrence of a marriage of Siri to the people of Makmur Village?

\section{METHOD}

The type of research used is empirical (sociological) legal research, namely legal research whose data is obtained from primary data or data obtained directly from the public. ${ }^{11}$ This research is a case study. Researchers in this study came directly to the location of the study to get several cases of the practice of the marriage of Siri marriage, as well as to obtain the necessary data, namely the informants who practiced the practice of marriage of Siri marriage in Makmur Village, Gambut District, Banjar District.

The approach used is a qualitative approach, which is an approach that reveals facts in-depth based on the scientific characteristics of individuals or groups to understand and reveal something behind a phenomenon. ${ }^{12}$ Researchers in uncovering the facts that are behind people's behavior using the method of observation and in-depth interviews with informants by referring to the interview guidelines.

11 Theresia Anita Christiani, "Normative and Empirical Research Methods: Their Usefulness and Relevance in the Study of Law as an Object," Procedia-Social and Behavioral Sciences 219 (2016): 201-207; Alexander J. Wulf, "The Contribution of Empirical Research to Law," J. Juris 29 (2016): 29.
This research is located in Makmur Village, Gambut District, Banjar District. The subjects in this study were the parties who practiced walimah in siri marriage in Makmur Village, Gambut District, Banjar Regency. The author uses seven informants as research subjects consisting of four cases. The object of this research is a general description and reasons for the occurrence of a series of marriage marriages in Makmur Village, Gambut District, Banjar Regency.

\section{RESULTS AND DISCUSSION Walimah of Siri Marriage}

Makmur Village Communities. If there is a wedding, those who carry out the marriage after the marriage contract is held. Those who hold walimah at their marriages mean that they have carried out the Sunnah which was recommended by the Messenger of Allah.

Walimah is the Makmur Village community that is not only performed on registered marriages but also unregistered marriages or Siri marriages. A marriage is considered valid if it meets the terms and conditions. There are five pillars of marriage, namely shighat (consent and

\footnotetext{
12 Bubaker F. Shareia, "Qualitative and Quantitative Case Study Research Method on Social Science: Accounting Perspective," Dimension 2, no. 5 (2016): 23.
} 
qabul), prospective husband / prospective bridegroom, future wife / prospective bride, two witnesses, and guardians.

Siri marriage in the cases for samples I, II, III and IV, all held Walimah. Even though their marriage was held after the marriage contract took place. Cases I, III and IV were held after the marriage contract was completed on the same day, whereas in case II it was held two weeks later after the marriage contract. In the case of the implementation of Walimah in cases I, II, III and IV, it has fulfilled as stipulated by fiqh, namely that Walimah can be held when the marriage ceremony takes place, or afterward, or when the bridegroom meets the bride, or afterwards. It can also be held depending on the customs and habits prevailing in the community because the procurement of walimah is a relatively free case in its implementation. ${ }^{13}$

Implementation although there are things that need to be considered, namely the implementation is adjusted to the prevailing traditions in the community but on condition that it cannot be

\footnotetext{
${ }^{13}$ Sayyid Sabiq, Fikih Sunnah, jilid III, terj. Abdurrahim dan Masrukhin (Jakarta: Cakrawala Publishing, 2011), hlm. 513.

${ }^{14}$ I bid., p. 507.

${ }^{15}$ Abdul Rahman, Perkawinan dalam Syariat Islam (Jakarta: Rineka Cipta, 1992), hlm. 39.

${ }^{16}$ Slamet Abidin dan Aminuddin, Fiqib Munakahat 1 (Bandung: CV Pustaka setia, 1999), hlm. 151.
}

accompanied by things that are prohibited by the Shari'a, such as drinking, mixing men and women and the like. ${ }^{14}$ Nor can there be any extravagance or extravagance in the performance of the artist. ${ }^{15}$ Walimah it can be held with any food according to ability. This was demonstrated by the Prophet. that the differences in holding walimah by him are not to distinguish or exaggerate one of the others but are merely adjusted to the situation when it is difficult or roomy. ${ }^{16}$ As the following hadith:

$$
\text { عن ثابت عن أنس قال ما أولم النبى } 17
$$

"From Thabit from Anas, he said," It is the Prophet. to make a ceremony at the time of marriage with one of his wives, just as he did with Zainab, he did a ceremony by slaughtering a goat. "18

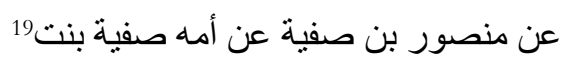
"From Mansur Ibn Safia, from her mother Safia bint Abi Shaybah, he said," The Prophet. held a blessing on part of his wife with (food) two mud sya'ir (wheat). "20

\footnotetext{
${ }^{17}$ Abī 'Abdillah Muhammad ibn Ismā'îl al-Bukhārī, Sahịh al-Bukhārì, juz III (Bandung: CV Diponegoro, tt), p. 2139.

${ }^{18}$ Ibn Hajar al Asqalani, Fathul Baari, vol 25, tr. Amiruddin (Jakarta: Pustaka Azzam, 2008), p. 452.

${ }^{19} \mathrm{Ab} \overline{1}$ 'Abdillah Muhammad ibn Ismā'îl al-Bukhārī, loc. cit.

${ }^{20}$ Ibn Hajar al Asqalani, op. cit., p. 474.
} 
Both of these traditions can be known that the Messenger of Allah. do not always hold walimah by slaughtering a goat, because in the second hadith it is stated that the Messenger of Allah. once held a walimah with two mud oats. The Hadith explains that holding walimah is per the abilities of each person.

Although siri marriage in cases I, III, and IV is carried out simply without being interfered with by matters that violate the provisions of Islamic law and without any luxuries that can bring immortality. When the marriage ceremony is over, the bride and groom who are legally married get together to sit together in a seat that has been decorated or called a wedding, and the bride also wears a wedding dress. For gratitude to Allah Almighty. the family invited the local community to attend the walimah by providing various kinds of food to be eaten by them. Walimah events in cases III and IV took place without singing accompanied by music or karaoke or other entertainment, while in case I accompanied by tambourines and poetry mawlid habsyi event.

Even though Siri's marriage in case II also takes place simply without any luxuries that can bring immortality. When the marriage contract is over, two weeks

\footnotetext{
${ }^{21}$ Ahmad bin Syu'aib al-Khurasani, Sunan anNasä' $\imath$, juz 5 (Beirut: Dar al-Fikri, tt), p. 127.
}

later, even though the marriage takes place. The bride and groom wear wedding clothes at the moment of Walimah, then gather to sit together at the aisle. The family provides a variety of foods to be served to guests in attendance. At that time those invited to the Walimah event were the surrounding community in Makmur Village and was attended by family and friends. The Walimah program takes place without any songs accompanied by music or karaoke, but there are traditional entertainment events such as baungsung and climbing pinang.

Based on the results of interviews about the implementation of marital marriage in cases I, II, III, and IV above, all informants said that the walimah held by them took place simply, without any luxury and waste. This means that the walimah they hold is based on their abilities and abilities, and the walimah has fulfilled what is meant by the walimah itself, namely the gathering of the bride and groom and serving food to guests.

Walimah in case I was accompanied by a tambourine punch and poetry maulid habsyi. This is by the words of the Prophet.

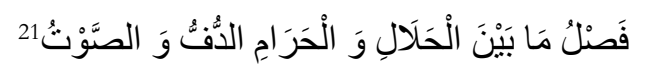


"The difference between the forbidden (adultery) and the forbidden (marriage) is by beating the tambourine and the sound."22

From Ayesha ra., She said; that the

Messenger of Allah. said:

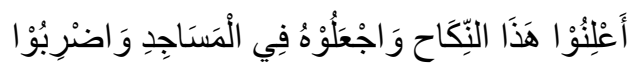

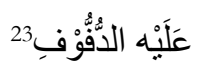

Based on the two traditions above, the Messenger of Allah. advocate announcing weddings and holding weddings by hitting tambourines and singing as a sign that a legal marriage has taken place. Hitting a tambourine and singing only occurs in case I only, whereas in cases II, III, and IV are not held.

Walimah in case II was organized by holding traditional entertainment such as baungsung and climbing pinang. Regarding traditional entertainment, it is not a problem to be held as long as it does not conflict with religious provisions. As Ahmad Azhar Basyir explained that there was no obstacle to entertainment, which

\footnotetext{
${ }^{22}$ Muhammad Nashruddin al-Albani, Sabih Sunan at-Tirmidhi, volume I, trans. Ahmad Yuswaji (Jakarta: Pustaka Azzam, 2007), p. 833.
}

did not result in suffocating guests and did not deviate from religious provisions. Customs are traditional symbols. However, if it conflicts with the principles of Islamic teachings, then there is no need to be turned on. ${ }^{24}$

The implementation of Walimah is an act that is committed, which in the case of the implementation is adjusted to the customs of the community as long as it does not contradict Islamic law. Besides the problem of luxury or simplicity depends on the ability of each person, but the priority is simplicity.

Walimah organized by the people of Makmur Village can be seen from cases I, II, III, and IV that have fulfilled what is meant by walimah and are under the provisions of the walimah itself, because in practice walimah in cases I, II, III, and IV there are no matters things that violate the provisions of Sharia.

\section{Reasons for Holding a Siri Marriage}

Holding a wedding ceremony for a marriage is an action that is not contrary to Islamic law. Holding walimah is one of the sunna that is highly recommended by the Messenger of Allah. Of course, every act that is offered, such as holding a

\footnotetext{
${ }^{23} \mathrm{Ab} \overline{1}$ 'İsā Muhammad bin İsā bin Saurah, Sunan atTirmïzī, juz 2 (Beirut: Dar al-Fikri, tt), p. 247.

24 Ahmad Azhar Basyir, Hukum Perkawinan Islam (Yogyakarta: Uji Press, 2000), p. 52.
} 
wedding ceremony, must have a good purpose.

One of the lessons learned from holding this event is to announce to the public that a marriage contract has taken place so that all parties know about it and there are no accusations in the future. ${ }^{25}$ Apart from that, it also holds alms as gratitude to Allah swt., As a sign of surrender of a girl to the husband of her parents, as an official sign of a marriage contract, as a sign of starting a new life for husband and wife, and as a realization of the sociological meaning of the marriage contract.$^{26}$

After examining the reasons for each informant in each case, the authors found that even though their Siri marriages were held for good reason by the intention of the Walimah itself, namely to announce to the public that a marriage contract had taken place so that all parties could find out. so that there are no accusations or slanders in the future. Also, other reasons such as wanting to hold a thanksgiving and wanting to gather and be friendly with the family is a good thing and does not conflict with Islamic law.

Holding a Walimah is a Siri marriage is an act that is common in the Makmur

25 Amir Syarifuddin, Hukum Perkawinan Islam di Indonesia antara Figh Munakahat dan Undang-Undang Perkawinan (Jakarta: Kencana, 2006), p. 157.
Village community, so the writer found that one of the reasons for holding a Walimah in their Siri marriage was because the act was already common in the Makmur Village community. According to the opinion of the writer, even though Siri marriages that are already common and carried out continuously, will eventually become a legal habit in the community.

Holding walimah for siri marriages for them is not an act to replace the position of marriage registration so that it is legal in the eyes of the country's law, it is still not officially state law but is already legally religious. They know about the marriage registration rules and know the legal consequences if they do not register marriages. They realize that has violated the laws and regulations, only prioritizing religious law, as long as it is legal according to religion then the marriage is legitimate. The people of Desa Makmur have no problem with siri marriage and do not make it a conversation. If the harmony and marriage conditions have been fulfilled, the marriage is valid even though it is not recorded in the KUA, and they consider that the registration of the marriage is only an administrative matter.

\footnotetext{
${ }^{26}$ Slamet Abidin and Aminuddin, op. cit., p. 156.
} 
Regarding the registration of the marriage can be arranged in the future. According to them, the people of Makmur Village, although married in a series of wars, were still organized by the Witnesses, because there was no desire to slander.

Based on the results of the interview, the authors found that those who held Walimah at Siri marriage knew about the marriage registration rules and realized they had violated them, but because they believed in religion, they did not bother with this matter.

According to Atho 'Muzhar marriage registration is an act to announce the marriage. Even though siri marriage cannot be considered as a substitute for marriage registration. Siri marriage is not considered a legal state because it does not have proof in the form of a marriage certificate, even though it is religiously valid and has been held though. The marriage certificate is evidence of recognition and guarantee of rights in the present. Weddings that are held even though they are not recorded can only be recognized by the surrounding community, while the actual marriage is not only recognized by the surrounding community but must also be recognized by the state and the wider community. This form of recognition appears in the form of writing, which is in the form of a marriage certificate.

The practice of walimah siri marriage occurs because the community considers that their marriage has fulfilled the harmony and requirements of marriage according to Islamic law. The Marriage Law does not validate a Siri marriage because it violates the provisions of Article 2 Paragraph (2) of Law No. 1 of 1974 concerning Marriage. If a child is born from a Siri marriage it is still considered an extramarital child and only has a civil law with his mother.

According to Quraish Shihab Siri marriage can lead to sin for the culprit because it violates the conditions set by the government. As a Muslim, it is only natural to obey Allah, the Messenger of Allah, and the government (Ulilal-Amr) as long as it does not conflict with the laws of Allah. As the word of Allah Almighty. in QS an-Nisa '/ 4: 59. The

regulation of marriage registration is a matter that does not conflict with the Koran, it has many benefits. Conversely, if you do not register the marriage will cause harm.

Also, the reason for their series of marriages is that the marriage age is not sufficient according to the Law as in cases II and IV, and also the incomplete administrative requirements to be 
recorded in the KUA as in cases I and III. According to them the cause is not a disgrace that must be covered up, because it does not affect the pillars and conditions of marriage, even though the requirements to be registered with the KUA do not fulfill but according to Islamic law the requirements for the marriage have been fulfilled, although not yet old enough to get married according to the Law Invite but according to Islamic law you can get married. For this reason, they held a ceremony for a Siri marriage.

According to the opinion of the writer, the community's opinion that marriage is not an act that must be covered up because it is already legally religious means that they have ignored the laws and regulations regarding marriage registration. The rules regarding recording must also be obeyed, and that does not obey them is a mistake. If the assumption continues like that, it will result in many Siri marriages.

Hold a series of marriages or unregistered marriages in addition to the benefits there are also disadvantages. The benefit of holding a series of marriages is to announce to the public so that slander does not arise, as a form of gratitude, and for friendship with the family. However, besides these benefits, it turns out that holding a Siri marriage also has a disadvantage, that is, holding a Walimah means that the Siri marriage is announced and can be known by the surrounding community so that it results in the community's view that Siri marriage is permissible, and in the end, many Siri marriage happens in the community. By conducting a marital marriage, it will also cause harm, among which is the nonimplementation of marital order in the community, the dignity, purpose, and purity of the marriage are unprotected, and the interests of husband and wife and their offspring cannot be protected. Siri marriage has bad consequences in domestic life. Therefore, to get rid of such harm, it is better not to do a series of marriage marriages. As in jurisprudence, it is stated as follows:

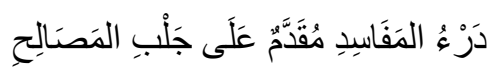

"Rejecting Interpretation takes precedence over achieving benefit" 27

The rule explains that if at the same time we are confronted with the benefit/aversion to harm/harm, we must accept benefit taking precedence is rejecting mediocrity. Because by rejecting

27 A. Djazuli, Jurisprudence Principles: The Rules of Islamic Law in Resolving Practical Problems (Jakarta: Kencana, 2014), p. 164. 
mediocrity, we gain benefit. The purpose of Islamic law itself is to achieve benefit in the world and the hereafter.

\section{CONCLUSIONS}

Based on the results of the research data obtained, it can be concluded that the marriage of Siri in the community of Makmur Village, Gambut District, Banjar District was carried out as in the marriage that was recorded. Walimah is carried out openly. Walimah is done based on the habits of the people of the Village of Makmur, which is carried out after the implementation of the marriage contract, both on the same day and several days after the marriage contract. Even though Siri marriage to the people of Makmur Village is simple. Walimah is by the provisions of Islamic law, because in its implementation not on matters that are contrary to the Shari'a.

The reason behind the occurrence of siri marriage to the people of Makmur Village, Gambut District, Banjar Regency is because it was done to announce to the public so that slander does not arise. After all, they want to hold a thanksgiving event at the same time to be able to stay in touch with distant families, and for other reasons, namely because of a marriage siri and holding walimah at the siri marriage are commonly carried out by the people of Desa Makmur. They have no problem with siri marriage and do not make it a conversation. For them, siri marriage is not something that should be covered up, because the marriage is legal according to religious regulations even though it is not recorded. Because of that, they held a ceremony for a Siri marriage.

Holding walimah at a series of marriages on the grounds of announcing to the public so that slander does not arise, it would be better to understand that the registration of the marriage is far better as an act to (declare) announcing the marriage. In this case, it is necessary to hold legal counseling or related socialization regarding the registration of marriage, to provide knowledge and understanding to the community, especially in the Village of Makmur, with the hope that a series of marriages will not be held again.

\section{REFERENCES}

Abidin, Slamet and Aminuddin, Fiqib Munakahat 1. Bandung: CV Pustaka setia, 1999.

al Asqalani, Ibnu Hajar . Fathul Baari, jilid 25, terj. Amiruddin. Jakarta: Pustaka Azzam, 2008

al-Khurasani, Ahmad bin Syu'aib. Sunan an-Nasāđ $\mathfrak{u}$, juz 5. Beirut: Dār alFikri, t.t.

Aziz, Nasaiy. "The Great Phenomenon of Online Sirri Marriage for Male and Female." Budapest International Research and Critics Institute (BIRCI- 
Journal): Humanities and Social Sciences 1, no. 3 (2018): 445-450.

Bahrum, Mukhtaruddin. "Legalisasi Nikah Sirri Melalui Isbat Nikah Menurut Kompilasi Hukum Islam." Jurnal Diskursus Islam 1, no. 2 (2013): 210-230.

Basyir, Ahmad Azhar. Hukum Perkawinan Islam. Yogyakarta: Uji Press, 2000.

Christiani, Theresia Anita. "Normative and Empirical Research Methods: Their Usefulness and Relevance in the Study of Law as an Object." Procedia-Social and Behavioral Sciences 219 (2016): 201-207.

Hafidzi, Anwar, and Norwahdah Rezky Amalia. "Marriage Problems Because of Disgrace (Study of Book Fiqh Islam Wa Adilâtuh and Kitâb al-Nikâh)." AL-IHKAM: Jurnal Hukum \& Pranata Sosial 13, no. 2 (2018): 273-290.

Khoiriyah, Rihlatul. "Aspek Hukum Perlindungan Perempuan Dan Anak Dalam Nikah Siri." Sawwa: Jurnal Studi Gender 12, no. 3 (2018): 397-408.

Lind Seal, Kirsten, William J. Doherty, and Steven M. Harris. "Confiding about Problems in Marriage and Long-Term Committed Relationships: A National Study." Journal of marital and family therapy 42, no. 3 (2016): 438-450.

Muhammad, Abī 'Abdillah bin Ismā'îl alBukhārī, Sahịh al-Bukhārì, juz III. Bandung: CV Diponegoro, t.t.

Munir, Arshad, and Naseem Akhter. "Marriage in Islam: An Analytical Study with a Special Focus on Non-Traditional Marriages in Pakistan." FWU Journal of Social Sciences 12, no. 2 (2018).
Muslim. Abī al-Husaini bin al-Hajjāj alQusyairi an-Naisābūri, Șhịh Muslim, juz II Indonesia: Maktabatu Rihlan, t.t

Rahman, Abdul. Perkawinan dalam Syariat Islam. Jakarta: Rineka Cipta, 1992.

Rofiq, Ahmad. Hukum Islam di Indonesia. Jakarta: Raja Grafindo Persada, 1995.

Sabiq, Sayyid. Fikih Sunnah, jilid III, terj. Abdurrahim dan Masrukhin. Jakarta: Cakrawala Publishing, 2011

Saebani, Beni Ahmad. Figh Munakahat (Buku I). Bandung: Pustaka Setia, 2001.

Shareia, Bubaker F. "Qualitative and Quantitative Case Study Research Method on Social Science: Accounting Perspective." Dimension 2, no. 5 (2016): 23.

Shomat, Abd. Hukum Islam: Penormaan Prinsip Syari'ah Dalam Hukum Indonesia . Jakarta: Kencana, 2010

Syarifuddin, Amir. Hukum Perkawinan Islam di Indonesia antara Fiqh Munakahat dan Undang-Undang Perkawinan. Jakarta: Kencana, 2006

Syukur, Abd. Kadir. Hukum Perkawinan di Indonesia. Barito Kuala: LPKU, 2015.

Wulf, Alexander J. "The Contribution of Empirical Research to Law." J. Juris 29 (2016): 29.

Zainuddin, Zainuddin \& Afwan. Kepastian Hukum Perkawinan Siri dan Permasalahannya Ditinjau dari Undang-Undang Nomor 1 Tabun 1974. Deepublish, 2017. 